\title{
The DeVelopment of A Digital Storybook AND AN AUGMENTED REALITY (AR)-BASED Proverbs APPLICATION
}

\author{
Jamilah Hamid $^{1}$, Nor Hasbiah Ubaidullah ${ }^{1}$ and Ahmad Yasir Bahador ${ }^{2}$ \\ ${ }^{1}$ Faculty of Arts, Computing \& Creative Industry, \\ Sultan Idris Education University, Malaysia \\ ${ }^{2}$ Sekolah Menengah Methodist, TgMalim, Perak, Malaysia
}

\begin{abstract}
Learning Malay proverbs is very important to sustain the rich heritage of the Malay civilization among young generations. However, pilot study and literature review show that students face problems in understanding proverbs when learning using conventional method. Thus, this paper discusses the development of a digital storybook to help the learning of selected Malays proverbs under the unity theme using Augmented Reality (AR)technology. The application development was divided into two parts; development of the AR-based proverbs application and the development of a digital story. For the first part, the application was developed based on the combination of waterfallmethodology,learning theory principles andAR application development guidelines. For the second part, the development isrelied on the digital story development guidelines. This application development can serve as important guidelines for the developers to develop suitable applications using AR technology to help students learn a range of important learning concepts.
\end{abstract}

\section{KEYWORDS}

Augmented reality, digital storybook, learning theory, Malay proverbs, mobile application.

\section{INTRODUCTION}

The current statistics show that the numbers of mobile applications Google's Play Store and Apple's App Store are 2.8 and 2.2 billion, respectively. In 20017 alone, a staggering number of applications had been downloaded[1]. In Malaysia, the number of smart phone users has increased to 11 million[2]. Despite such profound numbers of users, most applications are mainly based on the genre of online games[3], indicating that applications dedicated to learning are relatively low. Thus, all parties, notably the Ministry of Education, must embark on a new initiative to bring about a new paradigm shift that focuses on the use of mobile applications for education from the elementary level.

Naturally, this effort entails introducing more mobile educational software to school children. Clearly, mobile applications offer many benefits, such as they are relatively cheaper than desktop applications, support multimedia presentations and lifelong learning, engender appealing learning experiences, and reduce training cost (Elias, 2011; Crescente and Lee 2011, cited in[4]).Of late, the development of mobile applications has shifted from 2D and 3D technology to new graphics technology, notably Augmented Reality (AR) technology, which has been making an inroad into the domains of marketing, health, and education $[5,6]$. For example, in education, AR technology has emerged as a popular technology in developing a range of educational applications to help enrich and enhance the teaching and learning process at all educational levels from pre-education 
The International Journal of Multimedia \& Its Applications (IJMA) Vol.10, No.6, December 2018 to tertiary level[7-11].Arguably, its strong popularity owes to its ability to bring in a host of benefits for a diverse group of students. In this regard, the meta-review and cross-media analysis carried out by Radu[12]highlighted five main benefits of using AR for education, namely improved understanding, better learning language associations, enhanced long-term memory retention, improved physical task performance, improved collaborations, and increased students' attention. In view of these potential benefits, the use of such novel technology can help students to improve their learning performances, especially among low-achieving students[9].

Interestingly, a literature review performed by Koutromanos, Sofos, and Avraamidou[13]showed that mobile educational AR applications have been mostly used in the learning of science, with only a few being dedicated to the learning of other non-science subjects, such as language learning. Admittedly, several mobile AR-based applications have been developed for language learning[14], but almost all are mainly focused on syntax and spoken words. Thus far, mobile AR-based applications for the learning of proverbs, especially in Malay, are scarce. As acknowledged by many linguist scholars, Malay proverbs are a treasured legacy of knowledge that highlights the thinking of the Malays and the development of Malay civilization[15].On this matter, research by Ahmad Mahmood, Zaitul Azma, Nor Azuwan, and Norizan[16] showed that learning of proverbs could nurture of higher-order thinking skills (HOTS), whilst preserving the rich eastern cultures. More importantly, their research showed that learning of proverbs would have a profound positive impact on the development of national unity and the sense of belonging among various races in Malaysia[15]. Naturally, such unity developed at an early age would help students to be more tolerant and accommodative in their interactions when they enter colleges or universities, thus strengthening the bond among students of various ethnicities. As a nation with diverse races, religions, and cultures, Malaysia certainly needs such unity to guarantee a harmonious existence.

In the context of Malay language learning in Malaysia, proverbs are taught to both primary and secondary students. For assessment purpose, students have to sit in an examination to test their understanding of the topic, in which they are typically required to provide the corrects answers to several questions, such as follows: (i) to state the correct proverb based on a given picture, (ii) to give the right meaning of a given proverb, and (iii) to compose an essay using several given proverbs. Notwithstanding, the existing applications are nothing more than a digital representation of the contents of the textbook. For example, the Complete Malay Proverbs application only displays a collection of proverbs in the alphabetical order with the accompanying meanings without pictures. Admittedly, other applications do have 2D pictures, but they are not compelling enough to represent the true meaning of a proverb. Arguably, the 2D representations are not able to conceptualize the literal meaning of a proverb, thus making it very difficult to concretize the context in the graphical form. For example, the sistemguruonline (accessible at https://www.sistemguruonline.my/2017/04/peribahasa-bergambar.html) shows a list of 156 proverbs together with pictures, but such graphical elements are not relevant to the proverbs. Figure 1shows the proverbs and pictures of the sistemguruonline.

In addition, Johan[17]research findings suggest that primary school students would always face problems in learning proverbs as they tend to view the learning of subject matter to be boring. Such a perception is not surprising as they are not able to understand the underlying meanings embedded in the proverbs. Arguably, they would only read such proverbs and try to make sense of the meanings literally, without delving deeper into the context of such meanings. In fact, such a problem is not confined to school students but also to college and university students as well. A case in point is best exemplified by Hasmidar and Jafizah[18]study that showed education undergraduates majoring in the Malay Language were unable to accurately interpret the actual meanings of proverbs. The same researchers argued that such an inability was attributed to number of several factors, such as the lack of exposure to all types of proverbs, infrequent use of 
The International Journal of Multimedia \& Its Applications (IJMA) Vol.10, No.6, December 2018 proverbs in everyday life, lack of practice to help retain the meanings of proverbs, and inability to clearly explain the actual meaning of proverbs, even though they had sufficient understanding of the proverbs. Based on their reasons, it could be reasonably argued that the undergraduates lacked the essential knowledge of proverbs, thus resulting in their failure to understand the true meaning of the proverbs.

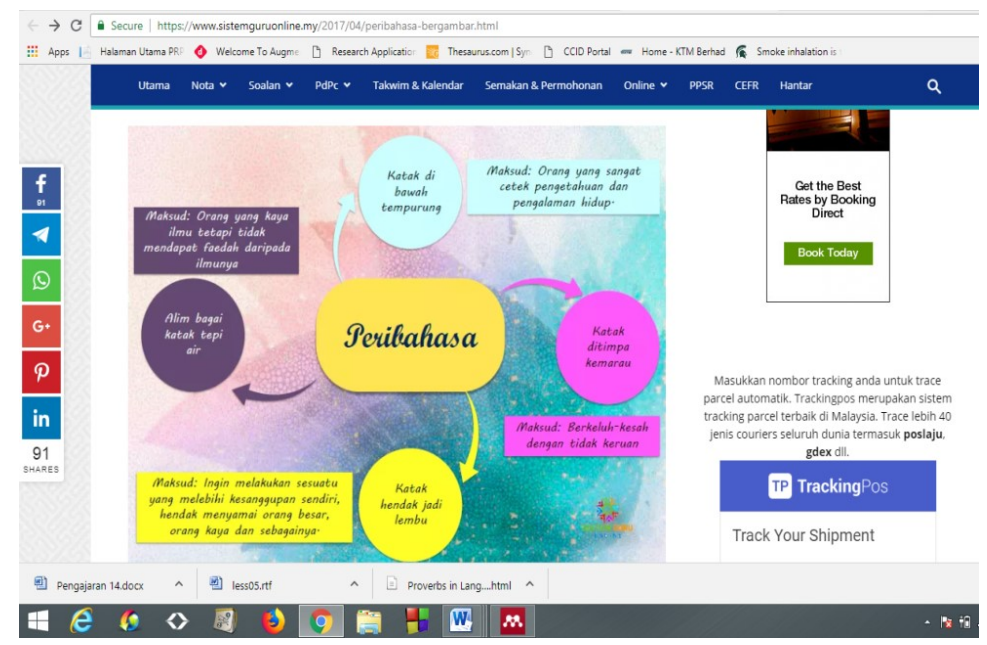

Figure 1: The proverbs and pictures of the sistemguruonline

In addition, a pilot study carried out by the present researchers found that some students were struggling to form a mental picture or to visualize a given proverb due to their unfamiliarity with some of the terms used in such a proverb. For example, virtually all the students were not able to form a mental picture of the proverb "jikalaumengangin, jangantumpahpadinya",as the word "mengangin" (which means to expose something to the wind flow) was unheard of in today's realm as far as they were concerned. Given this predicament, a new, novel approach is therefore needed in the learning of parables such that the latent parables could be represented in a better situation. In this regard, Ahmad Mahmood et al,. [16] recommends that the learning of proverbs should be based on oral activities, reading, and writing to increase the use of proverbs and to improve the mastery of the meaning of proverbs. On this matter, the use of digital storybooks seems appropriate to apply all the above three activities. Such use is in line with the assertion of Robin[19], who asserts that digital storytelling that combines text, pictures, audio narration, music, and video can help deliver a story more vividly. As such, AR technology is a potent educational tool for students at of all ages and grade levels[19-21]. Given the ample evidence supporting the use of AR technology in many areas of science learning, it therefore aptly that such a novel technology be applied to the learning of proverbs. In light of the issues discussed above, this study was carried out with the main aim of developing a digital storybook based on mobile AR technology to improve the learning of proverbs among school children. The discussion of this paper is dedicated to the development of digital courseware by focusing on the following:

i) The development of an AR-based digital storybook of proverbs.

ii) The development of an AR-based proverbsapplication. 
The International Journal of Multimedia \& Its Applications (IJMA) Vol.10, No.6, December 2018

\section{Methodology}

In general, the Instructional Software Design (ISD) model is used for the development of educational or instructional applications. However, the contemporary learning tools are more than just a learning tool, thus entailing new methodologies that are suitable for the development of training or learning tools using latest technologies available, such as AR or virtual reality (VR) technology. Clearly, the development of technology-based learning materials requires a new methodology thattakes into account two critical elements, namely the technological element and the educational element, with the former focusing on the chosen technology or platform and the latter paying greater detail to the educational aspects of learning or training. Therefore, the methodology used in this study for thedevelopment of the AR-based proverbs application was based on such integrated methodology that integrated both elements. In essence, the development of a novel AR application was divided into two as follows:

i. The development of an AR-basedapplication for each chosen proverb.

ii. The development of a digital storybook containing a story with the appropriate AR-based application.

For the development of the AR-based applications, the researchers used the Waterfall model with the AR development guidelines. On the other hand, the researchers used the digital story guidelines for the development of the digital storybook.

\subsection{The development of the AR-basedApplication for each chosen proverb}

The Waterfall model used for the development of the AR-based application for each chosen proverb consists of five phases as follows: (i)Requirement analysis, (ii) Design,(iii)Development and Coding, (iv) Testing,and (v) Maintenance. This development model was chosen based on the premise that the application is small, and the analysis and design phases could be carried out in detail prior to implementing the development process. In this paper, only the analysis and design phases are discussed.

\section{a. Analysis Phase}

In this phase, the main difference in the analysis between the educational software and the noneducational software is that the former had to deal with the educational elements.Specifically, the educational elements that had to be considered in this phase were thelearner analysis, instructional analysis, and objectives analysis.As such, to perform the threeanalyses these aspects, the researchers had to conduct a short interview with threeMalay language teachers in a secondary school. Table 1 summarizes the main findings of the interview with regards to the analysis of the educational elements.

As for the functional requirement, the applications could detect markers in the digital storybook without any problem. Instead of using the normal QR code (as presented by patterns as a marker), the proverbs of the AR applicationsthemselves served as markers that could be scanned (detected) by the camera of a smartphone. Figure 2 shows an example of a marker of the application based on the text of a Malay proverb in the digital storybook 
The International Journal of Multimedia \& Its Applications (IJMA) Vol.10, No.6, December 2018

Table 1: The background of learners, instructional and objectives analysis

\begin{tabular}{lrl}
\hline Educational Element & Description \\
\hline Learner & i. & Form-One students who attended apublic school. \\
ii. & Level of intelligence: Average and slow learner. \\
iii. & Gender: Female and Male \\
iv. & Prior knowledge \\
& - Could understand the Malay Language. \\
& - Could defineproverbs adequately \\
v. & Were able to use a tablet or a smartphone
\end{tabular}

Instructional Analysis $\quad$ i. $\quad$ Content: 10 proverbs based on the Bahasa MelayuForm-Onetextbook[22].

ii. Learning strategy would bestudent-centered. Hence, the students would use the application independently, with their teacher acting as a facilitator.

iii. The learning theory used was the Cognitive Learning Theory, with which one of the schema or concepts was employed in developing the appropriate instructions based on severalunifying themes for the learning content[23]. In this regard, the researchers developedtheshort digital story with the appropriate theme that wouldexplain several selected proverbs that are regularly used in the reallife,such that the students couldcomprehend the proverbs easily. According to this theory, information that lacks a theme can be difficult to comprehend, or, worse, the learner may "accrete" information using a wrong schema.Furthermore, digital storytelling can act as an platform to connect people of different races and cultures [21], which is extremely vital for Malaysia comprising a diverse population.

iv. Presentation of contents

a) AR-basedproverb apps - every proverb will be presentedin the graphical form, accompanied with relevant audio narration.

b) Digital storybook - each proverb will be included in and explainedby a short continuous story.

v. Type of technology - the digital storybookwas developed using the marker-basedmobile ARtechnology that supports all types of androidbased mobile devices. Essentially,the marker would be scanned by the device camera to launch the application.

Objectives of the applications
At the end of the lesson, the students should be able:

1. To explain the meaning of each proverb that is included in the applications and the digital story book.

2. To writea sentence using each proverbthat is included in the applications and the digital story book.

Assessment Not included in the applications.

\section{KUAT LILIT KERANA SIMPULNYA}

Figure 2: Amarker of the application based on the text of a Malay proverb

Admittedly, there are several typesof AR technology that are available; however, the researchers decided to use themarker-based AR technology due to its lower cost of ownership for teachers and suitability for young learners, such as 13-year-old students. From the development perspective, this type of AR helped the researchers to create digital storybooksconsisting markers, to which any smartphone camera can easily detect to launch the application with ease. For the 
The International Journal of Multimedia \& Its Applications (IJMA) Vol.10, No.6, December 2018

non-functional requirements, learnersmust be able to use the applications without any difficulties. Certainly, such requirements entailed the researchers to ensure the application can provide smooth, intuitive interactions, with which learnerscan perform learning tasks comfortably. In addition, 3D images and animations were used to highlight the meanings of proverbs more clearly, the understanding of which was further enhanced with relevant audios.

\section{b. Design Phase}

As highlighted previously, to helpstudents understand and acquire new knowledge easily, such new knowledge must be presented in aform with aunifying theme. Therefore, such a form was used by the researchers in the development of the digital short storybook. In this respect, a short story that is developed without the use of an innovative technology will lack features that can help attract users. Especially, in this digital age, students naturally expect to see attractive, appealing in their application. Failing to do so, students can become demotivated at best or frustrated at worst. On this particular matter, the AR technology has the capability to create innovative features and engender engaging learning environments, in which students can learning with a high degree of satisfaction and enjoyment, which can increase their understanding and long-term memory retention[9, 10, 12, 24]. Given such potential, thus researchers decided to develop the ARbasedproverb applicationbased on a short story, effectively transforming into a digital storybook with AR features.

To ensure a sound development, the researchers used the AR design guidelines as proposed byEndsley et al., [25], which was derived from the heuristics usability evaluation. Principally, there are nine (9) guidelinesare as follows: (i) Fit with user's environment and tasks, (ii) Form the communication function, (iii) Minimization of distractions and overload, (iv) Adaptation to user's positions and motion, (v) Alignment of the physical and virtual worlds, (vi) Fit with user's physical abilities, (vii) Fit with user's perceptual abilities, (viii) Accessibility of the off-screen objects, and (ix) Account ofthehardware capabilities. Table 2 summarizes the guidelines used in the design of the digital AR-based proverbs application.

Table 2: Theimplementation of the AR guidelines in the design phase.

\section{Item Design Guideline Implementation of the guideline}

1. Fit with the user's environment and The researchers decided to apply 3D animationsto task - AR experiences should use helpstudents visualize the metaphors in their physical visualizations and metaphors that have environment. Essentially, each proverb is presented by meaning within the physical and task each $3 \mathrm{D}$ animation. The use of such animations isneeded environments in which they are because some students have difficulty to interpret or presented. imagine several termsthat they have never heard or seen before. For example, the term "rebung", which means bamboo shoots, is rarely seen or heard nowadays in the digital world. Thus, by providing an appropriate 3D animation,the students will be able to discern the meaning of the related proverb more precisely. Table 3 shows three 3D animations to help students visualize the meanings of three proverbs.
2. Formation ofthe communication function.
All the 3D images and animations are representedin a real-life situation, which can be easily understood by the students.

3. Minimization of distractions and The 3D animation of each proverb only focuses on the 
The International Journal of Multimedia \& Its Applications (IJMA) Vol.10, No.6, December 2018

overload - the design should not be excessively cluttered, busy, or filled with too many movements. main element of the proverb. For example, the design of the proverbBagaiaurdengantebing only comprises bamboo trees, bamboo shoots, and the animation of a hand bending the bamboo shoots, without any text for the explanation of such a proverb. Moreover, the view pane has only four elements, namely a 3D animation in the view section, a $360^{\circ}$ view button, an audio icon, and an exit icon. In addition, an audiocan be played only once, but it can be replayed if needed.

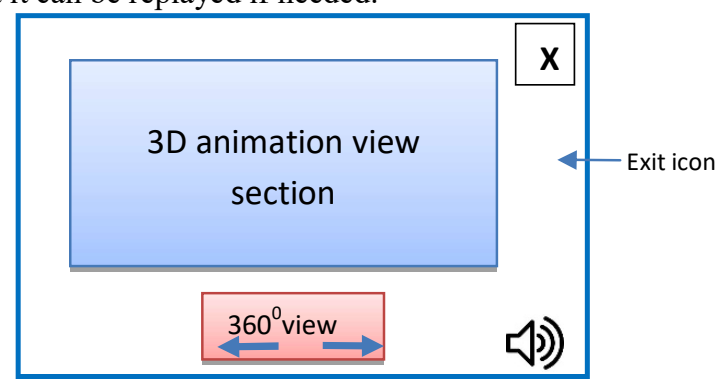

The application should allow the user to view the contents in $360^{\circ}$ such that he or she can view an object from any angle. The button for the $360^{\circ}$ viewing is provided, with which the user can slide to the right or to the left to find the angle that he or she finds fitting. useful and usable as seen from various viewing angles, distances, and movements made by the user.

5. Alignment of the physical and virtual worlds - the placement of virtual elements should make sense to the user in the physical environment.

$6 \quad$ Fit with user's physical abilities interacting with the AR-based application shouldbe simple and intuitive, not challenging or complicated.
As the AR-based application would be implemented using a tablet, the virtual objects would appearat the top of the digital storybook.
Considering that the mean age of the intended users' is 13 years, the researchers designed the application with minimal use of physical activities. As such, all the interactions for this applicationuse only the touchscreen. To start the application, the user only needs to touch the application icon and followed by clicking the start button. To makea 3D animation appear, the user only needs to hold the tablet and scan a target displayed on the digital storybook. Other interactions can be carried out by touching the audio icon to repeat an audio or by touching the $360^{\circ}$ buttonto view an object from several different angles.
7. Fit with the user's perceptual abilities - the designers should consider the size, color, motion, distance, and resolution when designing the ARbased application such as to fit with the user's perceptual ability.
The 3D images created should reflect real images in terms of shape, color, and size. The size of images is designed for the 8" display screen. Likewise, the animations used should showthe proverbs realistically using the real motion. For example, the animation of an ant carrying food should use the proper motion that realistically mimics the ant's motion.

\section{Accessibility of off-screen objects.}

Not applicable as the AR-based applicationdoes not have any off-screen objects. 
The International Journal of Multimedia \& Its Applications (IJMA) Vol.10, No.6, December 2018

9. Account of the hardware capabilities. In this aspect, the researchers had to take into consideration the cost of procuring the required hardware, namely a tablet, which is typically priced at about USD 145.00 - USD160.00. Thus, whendesigning

the AR-basedapplication, the researcherssought the minimum requirements of the system, which falls under the price range, as follows:

- OS: Android 6.0.

- CPU: Quad-core 1.0 GHz

- DISPLAY: 8.0 inches $(\sim 70.7 \%$ screen-to-body ratio) $800 \times 1280$ pixels

- CAMERA: 5MP REAR, 2MP FRONT

- $\quad$ STORAGE/RAM: 2 GB RAM, 16 GB ROM

Table 3: The suggested types of the 3D animations for the three proverbs

\begin{tabular}{|c|c|c|c|}
\hline Item & Malay proverb & $\begin{array}{l}\text { Literal translation in } \\
\text { English }\end{array}$ & $\begin{array}{l}\text { The suggested type of the } 3 D \\
\text { animation }\end{array}$ \\
\hline 1. & melenturbuluhbiardarirebungnya & $\begin{array}{l}\text { If wants to bend the } \\
\text { bamboo, must do it } \\
\text { during bamboo shoots }\end{array}$ & $\begin{array}{l}\text { The selected animation of } \\
\text { bending of bamboo shoots shov } \\
\text { that the bamboo shoots can be be } \\
\text { without breaking, which is not t } \\
\text { case for the matured bamboo. }\end{array}$ \\
\hline
\end{tabular}

2. Taklapukdekhujan, taklekangdekpanas
Neither besmircheddue to the rains, nor crackeddue to the hot sun.
The selected animation shows a house that remains erect and beautiful under a hot sun or heavy rains.

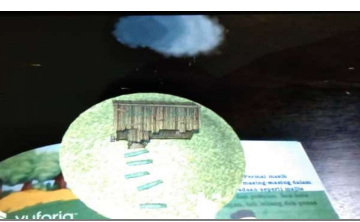

3. Sepertikatak di bawahtempurung Like a frog under a shell The selected animation shows a frog having a clear vision of theoutside world when the shell is liftedabove it, and the vision returns to darkness whenthe shell is closed.

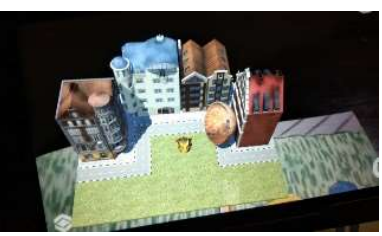


The International Journal of Multimedia \& Its Applications (IJMA) Vol.10, No.6, December 2018

\subsection{The Development of the Digital Storybook}

According to Santos et al.,[14], a language is usually shaped by the prevailing physical, social, and cultural aspects of a particular environment in which people interact with one another. In the same manner, a proverb comes into being in response to an event or incident. Based on this premise, the researchers used a short digital story to explain each selected proverb of the ARbased proverbs application. As highlighted previously, the selection of the proverbs was based on the Form-One Malay Language textbook consisting of 10 proverbs[22]. Specifically, the development of the digital storybook was based on the digital story development guideline proposed by Robin[19]. Based on this guideline, the first step involves choosing a particular topic of interest. In concert with the cognitive development theory, the needs of thematic requirements in delivering a specific concept to students must be given a strong emphasis such as to the students will be able to understand the context of learning more efficaciously[23]. As such, the researchers proposed a relevant topic called "Kampungku Kampung Permai" (My Village is a Harmonious Village) that is premised on an appropriate theme that reflects the diverse communities in Malaysia. More importantly, this theme provides a penetrating view of the importance of unity and harmony of various segments of the Malaysian population. According toMohdMahzan et al.,[15], the learning of Malay proverbs can not only teach students the creative and critical thinking of the Malays during the peak of their civilization but can also provide an effective means in developing and nurturing the national unity among diverse Malaysians. In addition,Basir[26] asserts that the concept of unity must be understood and celebrated by all races in Malaysia, which can be infused in the learning activities as the primary level of education. In this study, the focus was on the curriculum of the lower secondary school for Form-One students, whose ages were relatively young and untainted minds could be imbued with noble values of a caring, tolerant society.

In the digital storybook, the concepts of good manners, cooperation, accountability, collaboration, and harmonious co-existence among various races in a village are emphasized. Admittedly, not all the selected proverbs were based on the theme of unity, such as "Katak di bawahtempurung" (A frog living under a shell). As such, the researchers were compelled to create several interesting short stories based on such a theme. The second step of the guideline involves the composition of the scripts of a story. The guideline stresses that the scripts mustto be composed as a focused, personal, and shortnarrative, which has an interesting beginning, an engaging storyline in the midway of the story, and a good ending, the emotional elements of which can be embedded in the story using relevant audio. Based on this guideline, the researchers created the main character of a person representing a small boy living in a small village that is used throughout the storytelling. More specifically, the story was composed as a short composition consisting of only 15 pages, of which 10 have several scripts containing the selected proverbs.

The storybegins at a location of the village, showing the name of the village and highlighting the concept of unity and harmony practiced in the village. In the midway of the story, an incident involving a villager is presented to the users, with the aim to invoke a sense of an emotional feeling. The story culminates in an ending, showing a peaceful, harmonious village in which, all its members are helpful, caring, not selfish nor unmindful. In addition, this digital story does not have an audio, as such a source of information is used in the AR-based proverb application. The final step of the guideline focuses on the preparation of relevant images for a given story. In this step, the researchers developed an image that depicts a typical village environment in Malaysia. More importantly, the image was craftily created to highlight the selected proverbs more vividly and clearly, such as to be in line with the objectives of the educational courseware. For example, Figure 3 shows a proverb called "kuatlilit kerana simpulnya", which literally means "united we stand, divided we fall" to emphasize the concept of unity. Figure 3 depicts the image showing the "kuatlilit kerana simpulnya" proverb. 
The International Journal of Multimedia \& Its Applications (IJMA) Vol.10, No.6, December 2018

Finally, the following step of the guideline focuses on the story development in digital form. In this study, however, the application for the story was developed separately, except the target that would be scanned by the application was inserted in the story.

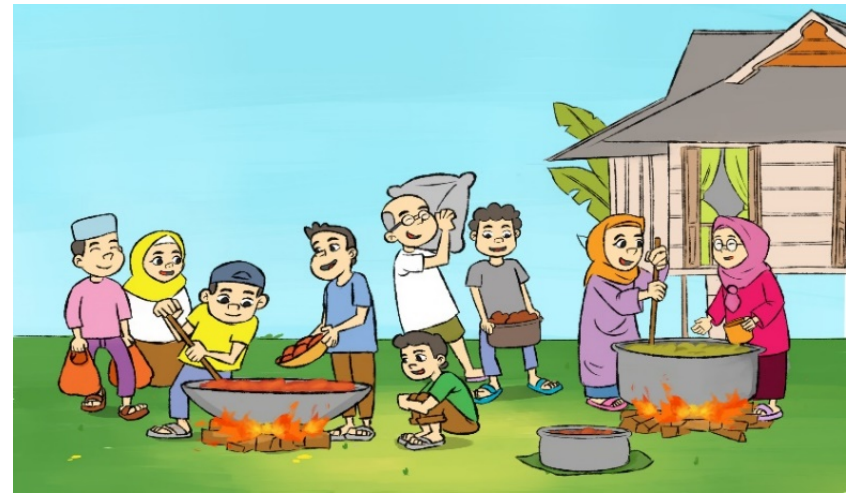

Figure 3. The image presenting the "kuatlilit kerana simpulnya" proverb

\section{CONCLUSION}

Undeniably, the learning of proverbs is important not only for preserving this unique Malay heritage but also for the objective of attaining and sustaining strong, sound national unity among diverse groups of Malaysians. To achieve such a sense of togetherness, obviously, education plays a pivotal role. Only through education, can Malaysians, especially young children, learn to appreciate and practice such a concept in their everyday lives. As such, students must be exposed to activities that can help them develop strong bond irrespective of their religious beliefs, the color of their skins, or social background. In this regard, learning the appropriate Malay proverbs that touch on the theme of unity can help students to develop national unity at the early age of their formal learning. Admittedly, teaching Malay proverbs can be a daunting task as some proverbs are not easily discernable to the uninitiated, notably to young students. Further compounding this predicament, the existing learning approach is not effective enough to motivate students to learn the subject matter. Clearly, a more efficacious learning method is needed to help mitigate such a problem. Against this backdrop, this study was carried out with the main aim to develop a novel mobile learning application in the form of a digital storybook of proverbs with the use of the marker-based AR technology. In developing such an innovative learning application, a methodology combining the system development guidelines and educational application development principles were used to ensure such an application will be able to make the learning of Malay proverbs more engaging, enjoyable, and efficacious. Surely, the use of such potent learning application can have a profound impact on students' learning performance and motivation, which can ultimately help them to forge strong national unity, a social construct that can make Malaysia a safe, peaceful place to live in. Lastly the development of this application can serve as important guidelines for the developers to develop suitable applications using the AR technology to help students learn a range of important learning concepts.

\section{ACKNOWLEDGMENT}

The researchers wish to extend their gratitude to the Research Management Centre, Sultan IdrisEducation University for the research grant (2017-0303-107-01) that helped fund this study. 
The International Journal of Multimedia \& Its Applications (IJMA) Vol.10, No.6, December 2018

\section{REFERENCES}

[1] The Statistics Portal. (2017). Retrieved August 17, 2017, from https://www.statista.com/topics/1002/mobile-app-usage/

[2] Syahar, A. (2016). Pengguna telefon pintar cecah 11 juta. Retrieved August 17, 2017, from http://www.utusan.com.my/bisnes/korporat/pengguna-telefon-pintar-cecah-11-juta-1.181716].

[3] Mariah, A. (2016). 10 trend penggunaan aplikasi mudah alih di Malaysia. Retrieved August 17, 2017 , from http://www.astroawani.com/berita-teknologi/10-trend-penggunaan-aplikasi-mudah-alih-di-mal aysia- 122355

[4] Mehdipour, Y., \& Zerehkafi, H. (2013). Mobile learning for education: Benefits and challenges. International Journal of Computational, 3(6), 93-101 (251-259). https://doi.org/10.1080/87567555.2011.604802

[5] Ma, M., Fallavollita, P., Seelbach, I. N. A., Heide, A. M. V., Euler, E., Waschke, J., \& Navab, N. (2016). Personalized augmented reality for anatomy education. Clinical Anatomy, 453, 446-453. https://doi.org/10.1002/ca.22675

[6] Londei, R., Esposito, M., Diotte, B., Weidert, S., Euler, E., Thaller, P., Fallavollita, P. (2015). Intraoperative augmented reality in distal locking. International Journal of Computer Assisted Radiology and Surgery, 1395-1403. https://doi.org/10.1007/s11548-015-1169-2

[7] Antonioli, M., Blake, C., \& Sparks, K. (2014). Augmented reality applications in education. The Journal of Technology Studies, (2009), 96-107.

[8] Nazatul-Aini, A. M., \& Nooraidah, K. H. (2014). Mobile learning application based on augmented reality for science subject: Isains. ARPN Journal of Engineering and Applied Sciences, 9(9), 14551460 .

[9] Lu, S., \& Liu, Y. (2015). Integrating augmented reality technology to enhance children's learning in marine education. Environmental Education Research, 4622. https://doi.org/10.1080/13504622.2014.911247

[10] Redondo, E., Rierra, A. S., \& Fonseca, D. (2015). Geo-located teaching using handheld augmented reality: Good practices to improve the motivation and qualifications of architecture students. Universal Access Inf Soc, 14, 363-374. https://doi.org/10.1007/s10209-014-0362-3

[11] Yilmaz, R. M., Kucuk, S., \& Goktas, Y. (2016). Are augmented reality picture books magic or real for preschool children aged five to six ?. British Journal of Educational Technology. https://doi.org/10.1111/bjet.12452

[12] Radu, I. (2014). Augmented reality in education: A meta-review and cross-media analysis. Pers Ubiquit Comput, (18), 1533-1543. https://doi.org/10.1007/s00779-013-0747-y

[13] Koutromanos, G., Sofos, A., \& Avraamidou, L. (2015). The use of augmented reality games in education: A review of the literature. Educational Media International, 52(4), 254-271. https://doi.org/10.1080/09523987.2015.1125988

[14] Santos, M. E. C., Lübke, W. A. ., Taketomi, T., Yamamoto, G., Rodrigo, M. M. T., Sandor, C., \& Kato, H. (2016). Augmented reality as multimedia: The case for situated vocabulary learning. Research and Practice in Technology Enhanced Learning, 11(4), 1-23. https://doi.org/10.1186/s41039-016-0028-2. 
The International Journal of Multimedia \& Its Applications (IJMA) Vol.10, No.6, December 2018

[15] Mohd Mahzan, A., Noor Azam, A. R., Noraziah, M. A., \& Abdul Razq, A. (2015). Mesej perpadauan dalam buku teks Bahasa Melayu Tingkatan 4 dan 5: Analisis terhadap Bahasa Melayu(The social unity message on the form 4 and 5 Malay language textbooks: Analysis Malay proverbs). Jurnal Pendidikan Bahasa Melayu -JPBM (Malay Language Education Journal MyLEJ), 5(Mei), 44-52.

[16] Ahmad Mahmood, M., Zaitul Azma, Z. H., Nor Azuwan, Y., \& Norizan, C. S. (2011). Pengetahuan makna peribahasa dalam kalangan pelajar sekolah menengah. Jurnal Linguistik, 13, 1-16.

[17] Johan, A. (2010). Pembelajaran peribahasa dalam kalangan murid sekolah rendah. Perkongsian Profesional Bagi Guru-Guru Permulaan. Singapore: Ministry of Education, Singapore. Retrieved from http://malaylanguagecentre.moe.edu.sg/qq1/slot/u181/KhazanahIlmu/Perkongsian Profesional/MLCSFinal-65-81.pdf

[18] Hasmidar, H., \& Jafizah, J. (2016). The interpretation of proverbs and their relation to thinking skills: An analysis based on relavance theory. Jurnal Bahasa, 16(1), 94-119.

[19] Robin, B. R. (2016). The power of digital storytelling to support teaching and learning. Digital Education Review, (30), 17-29.

[20] Yuksel-arslan, P., Yildirim, S., \& Robin, B. R. (2016). A phenomenological study: teachers ' experiences of using digital storytelling in early childhood education. Educational Studies, 42(5), 427-445. https://doi.org/10.1080/03055698.2016.1195717

[21] Grant, N. S., \& Bolin, B. L. (2016). Digital storytelling: A method for engaging students and increasing cultural competency. The Journal of Effective Teaching, 16(3), 44-61.

[22] Mardian Shah, O., Solehah, M., \& Beseknorliana, R. (2016). Buku Teks Bahasa Malaysia Tingkatan 1. Kuala Lumpur: Dewan Bahasa dan Pustaka..

[23] Yilmaz, K. (2011). The cognitive perspective on learning: Its the cognitive perspective on learning: Its theoretical underpinnings and implications for classroom practices. The Clearing House: A Journal of Educational Strategies, Issues and Ideas, 8655. https://doi.org/10.1080/00098655.2011.568989

[24] Bower, M., Howe, C., Mccredie, N., Robinson, A., \& Grover, D. (2014). Augmented Reality in education - cases, places and potentials. Educational Media International, 51(1), 1-15. https://doi.org/10.1080/09523987.2014.889400

[25] Endsley, T. C., Sprehn, K. A., Brill, R. M., Ryan, K. J., Vincent, E. C., \& Martin, J. M. (2017). Augmented reality design heuristics: Designing for dynamic interactions.In Proceedings of the Human Factors and Ergonomics Society 2017 Annual Meeting (pp. 2100-2104). https://doi.org/10.1177/1541931213602007

[26] Basir, N. (2012). Perpaduan etnik menerusi penggunaan bahasa melayu. Kangar, Perlis. Retrieved from https://www.researchgate.net/publication/269223543\%0APERPADUAN. 
The International Journal of Multimedia \& Its Applications (IJMA) Vol.10, No.6, December 2018 AUTHORS

Dr. Jamilah Hamid is as a Senior Lecturer in Faculty of Art, Computing and CreativeIndustry,Sultan Idris Education University. She holds a Bachelor of Science in Education (Hons.) majoring inMathematics and Master of Science (Information Technology). She obtained her PhD inInternet and Web Computing from Sultan Idris Education University, Malaysia. She hasbeen teaching in high education institutions since 1991 in several subjects such asProgramming, Methodology in Courseware Development, Educational Technology andTeaching Methodology. Her research interests are on Virtual Reality, Augmented Reality, Educational Technology and EducationalSoftware.

Dr. Nor HasbiahUbaidullah is working as an Associate Professor at Universiti Pendidikan Sultan Idris. She received degree in Computer Science from Universiti Kebangsaan Malaysia and Master of Science in Information System from University of Salford. She obtained her $\mathrm{PhD}$ degree in Information Technology from Universiti Kebangsaan Malaysia. Her research areas include Courseware Engineering, DSS,Learning Disability Children, Systems/ Product Development, Programming $\mathrm{C}++$ and JAVA.

Ahmad Yasir bin Bahador is a secondary school teacher at SMK Methodist. He holds a certificate in education majoring in PengajianMelayu from Kota Baharu Teaching Collage. He obtained a bachelor degree in IT Education and Master degree in Multimedia Education from Universiti Pendidikan Sultan Idris, Malaysia. He hasbeen teaching in school since 1997 in several subjects such asBahasa Melayu (Malay Language), Kemahiran Hidup (Life Skills), LiterasiKomputer(Computer Literacy)and AsasSainsKomputer (Basic Computer Science). He has 12 years' experience in teaching Form 1 Bahasa Melayu. His research interests are on Educational Technology and Educational Software.
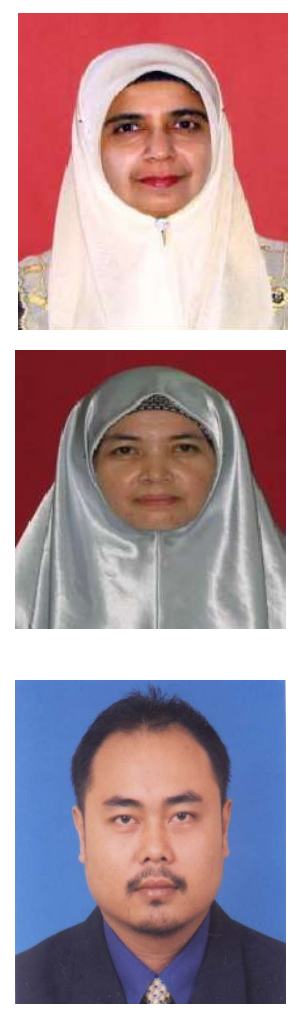